\title{
A Comparative Analysis of Crime Stories Published in leading English Newspapers of Delhi Edition
}

\author{
Eqbal Ahmad \& Ramendra Nath Verma \\ (SCADMS) Sharda University Greater Noida, U.P. Email: ramendranath12@gmail.com
}

\begin{abstract}
With the boom in media industry in India, News has become a product to be consumed by the readers and viewers and, thus, sold in terms of attracting revenue by boosting circulation and rating than providing pure information to aware the mass and empower people. In most cases, news is determined on the basis of public craze, not requirement. This fact of Indian journalism has led to over emphasis on Sensational, Political and Crime Reporting. Today, Crime reports have taken a major place in Newspapers. Because of the immense popularity of crime as a topic of news, there has been no shortage of research on how crime is covered by the media. The present study examines crime news coverage in the leading English Newspapers. The national dailies have been examined against the backcloth of Indian culture and social settings. Comparative analysis was followed to study the objectives and hypothesis. Some prominent facts came into light through this research like Hindustan Times had covered more number of stories by giving maximum coverage to the crime news than the other national dailies while in The Times of India, maximum stories related to terrorism were published. Overall the study tried to analyze the crime reporting in English newspapers through comparative analysis.
\end{abstract}

Keywords: Media, Newspaper, Crime news, national dailies

\section{INTRODUCTION}

Crime and violence has been a significant component of news coverage since earliest newspapers. This coverage is primarily framed either on law enforcement or from criminal justice point of view. Beyond these basic frames however modern analysis of crime and violence news reveals significant violations of principles of quality coverage. Even more disturbing, there is growing evidence that the problems of news coverage of crime and violence do significant damage to news consumers, who rely on this information for their perceptions and responses to the role of crime in their communities. Many researchers argue that news about crime and violence is degraded.

As part of a large-scale study of juvenile delinquency and public perceptions and attitudes regarding youthful misconduct in India, India newspapers were content analyzed for the extent of their crime-news coverage. The data demonstrate that crime-news coverage resembles the different pattern found in countries like the United States. Crime news was a staple, albeit a small portion, of the newspapers' space, closer to the lower percentages in Western newspapers. But unlike Western newspapers, the Indian Media focus is on the illegal conduct of public officials and public-disorder events, such as riots and demonstrations. Personal-crime coverage tends to receive less attention in Indian newspapers than it does in the United States. To some extent, as in the Western world, the Indian newspapers present a mediated image of crime.

(c) AesthetixMS 2019. This Open Access article is published under a Creative Commons Attribution Non-Commercial 4.0 International License (http://creativecommons.org/licenses/by-nc/4.o/), which permits non-commercial re-use, distribution, and reproduction in any medium, provided the original work is properly cited. For citation use the DOI. For commercial re-use, please contact editor@rupkatha.com. 
English Newspapers, in recent years, have generally drifted away from general issues to crime and violence, analyses of major social problems, and investigations of governmental and corporate wrongdoing. Therefore, it is now common to find crime stories splashed with big headlines even on the front page of major newspapers. Thus, the need to study the coverage of crime reporting in major English newspapers in Delhi is bound to throw up exciting findings.

Hence, the need was felt to analyze the content of crime coverage in the newspapers published in Delhi Edition.

\section{RESEARCH OBJECTIVES}

1. To study and critically analyze the nature and type of crime stories reported in the English newspapers.

2. To study the crime done by bureaucrats, politicians and influential people.

3. To study the crimes committed on women which are reported in English newspapers?

\section{RESEARCH METHODOLOGY}

Content analysis gives to a certain extent an accurate view of investigation and has been taken as a tool of investigation for the purpose of this study. It is a time tested method and several researchers in the field of mass communication has adopted and also advocated content analysis as an effective tool for research purposes. Content analysis could determine the extent of newspaper reporting in terms of amount of space or number of articles. 'The present study will be adopted content analysis to study the space devoted for crime coverage in selected English newspapers published in Delhi edition.

The study tries to investigate and evaluate the content through Random Sampling.

\section{Analysis of crime coverage}

A thorough reading of various newspapers magazines, textbooks and journals was made to understand the different types of crime. Then a close analysis was done to categorize the crime into different categories which were published as rime news in the English newspapers. Quantitative analysis was carried out to find the opinion of the readers towards crime reporting in English newspapers.

The research design is descriptive in nature. Descriptive research is a systematic, empirical inquiry in which the scientist does not have control of the independent variables because their manifestations have already occurred or because they are inherently not manipulated. Survey method was followed for this section of the study. The primary data was also collected through structured questionnaire.

\section{Sampling Methodology}

As this research to be pertained to the study of the Delhi Edition of the selected samples of English newspapers was taken from Delhi city. The sample size was of 300 and the readers were selected using random sampling technique. The address of subscribers of the selected newspapers was provided by the newsagents. From the list of readers given by the newsagents, the readers were selected randomly. Thus the feedback of readers was also taken to substantiate the study. 


\section{Analysis of Data}

The data obtained through the questionnaire was coded, classified and tabulated for further statistical analysis. Descriptive statistical analysis was done to present the responses of the readers.

\section{LITERATURE REVIEW}

Chandan Mukherjee, Preet Rustagi and N. Krishnaji (2001), "Crimes against Women in India: Analysis of Official Statistics" Economic and Political Weekly, Vol. 36, No. 43 (Oct. 27 - Nov. 2, 2001), pp. 4070-4080

They attempt to see what official, published data reveal, whether there are clear-cut regional patterns and if so whether they can lead to meaningful hypotheses for future work. There are some significant researches being conducted by scholars in finding important factors influencing reporting behavior of victims of violence.

C. S. H. N. Murthy, Challa Ramakrishna and Srinivas R. Melkote, Journal Media and Communication Studies Vol. 2(2) pp. 039-053, February, 2010

A critical analysis of the first page reporting priorities of the four leading news papers- The Hindustan Times, The Indian Express, The Times of India (all being published from New Delhi and Lucknow) and The Hindu (Only from New Delhi and Southern States) reveals a number of interesting shifts in the paradigms of news reporting and values.

The analysis, which involves the first page news coverage (including headlines, type of content, photos and advertisements), offered an insight into the departures from the traditional news values.

Kaveri Devi Mishra, Sridhar Krishnaswami, Citizens Journalism in India: a Case Study of Delhi, Journal of Education \& Social Policy Vol. 1 No. 1; June 2014

At a time when the main stream media is seen diverting from its objective and focusing more on profit making motive many social and vital issues and stories relating to the masses are either neglected or rejected by the media that has led to a huge gap between issues reported and neglected. This paper evaluates and analyzes the emergence, trend, and role of Citizen Journalism with explicit reference to Delhi Gang rape - Nirbhaya case in 2012. The paper at the end raises concerns on the ethics and to what extent unfiltered information can reach the masses and strike a balance in the society.

Jason Burke, The problem with crime against women in Delhi, https://www.theguardian.com/commentisfree/2011/feb/22/problem-crime-againstwomen-delhi

Almost every day, local newspapers carry stories covering the latest incidents of rape or harassment. In a metropolis with a population of between 12 and 18 million, depending on whether satellite towns are counted, some such cases are inevitable but the recent wave of violence against women has provoked a spate of outraged reports. Delhi had seen 25 cases of rape, including several brutal gang rapes, and 42 "molestations" in the last month. One Englishlanguage local newspaper ran the banner headline of "Shame on Delhi Men".

Kriti Singh, A Small Study On Impact Of Crime Against Women News Stories On Indian Urban, Imperial Journal of Interdisciplinary Research, Vol-2, Issue-3, 2016

The research paper is an attempt to gauge the impact of crime news stories related to women on urban women based in urban areas of India. The paper tries to analyze the crime news 
consumption habits in urban women and what impact does these news stories create in the mind of women.

\section{ANALYSIS AND FINDINGS}

1. To study the nature and type of crime reported in the English newspapers of Delhi Edition From the research study, it came to light that in Hindustan Times highest numbers of crime stories were reported (891) followed by Times of India (792), The Hindu (744) and The Indian Express (744).

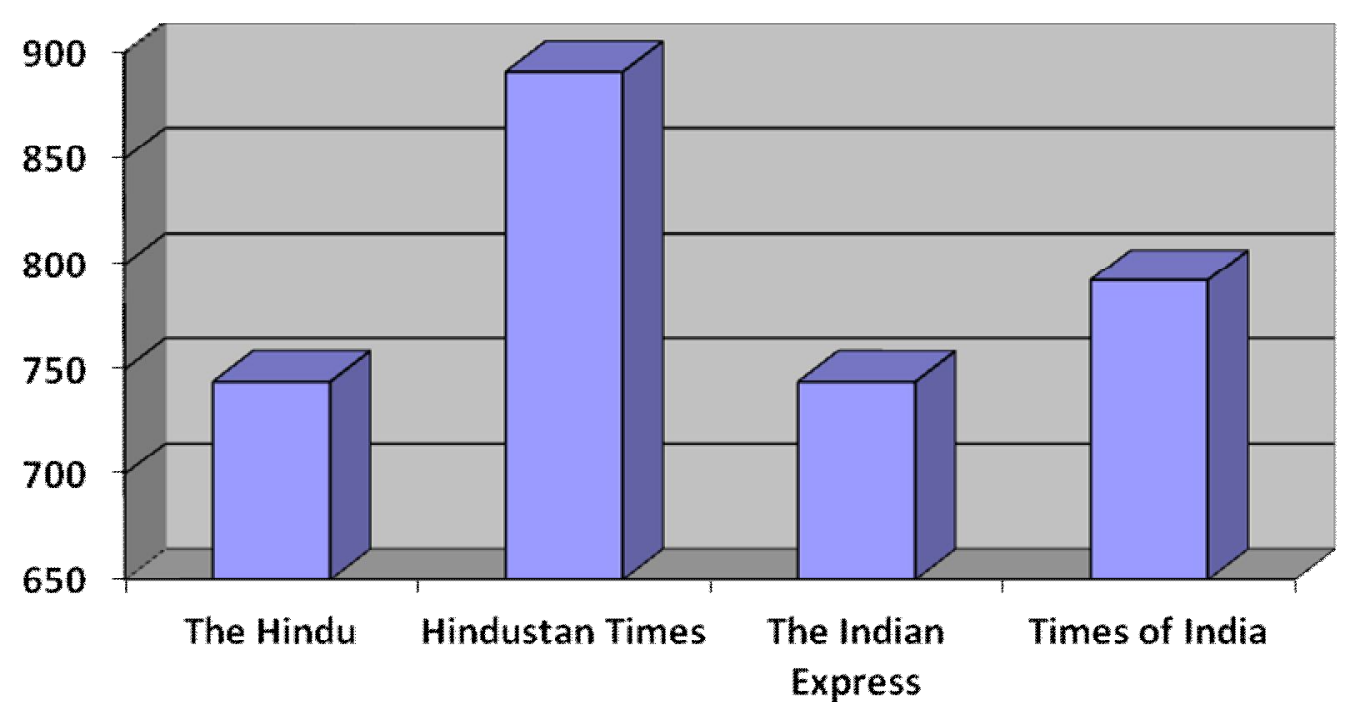

However, The Indian Express (98,099.91sq $\mathrm{cm}$ ) gave highest space coverage to crime stories followed by The Hindustan Times $(81,256.24 \mathrm{sq} \mathrm{cm})$, Times of India $(79,549.05 \mathrm{sq} \mathrm{cm})$ and The Hindu $(68,289.92 \mathrm{sq} \mathrm{cm})$.

2. Crime stories most often reported

In the four national dailies (The Hindu - 168, Hindustan Times - 153, The Indian Express - 193, Times of India -153) crime stories related to terrorism were given maximum importance.

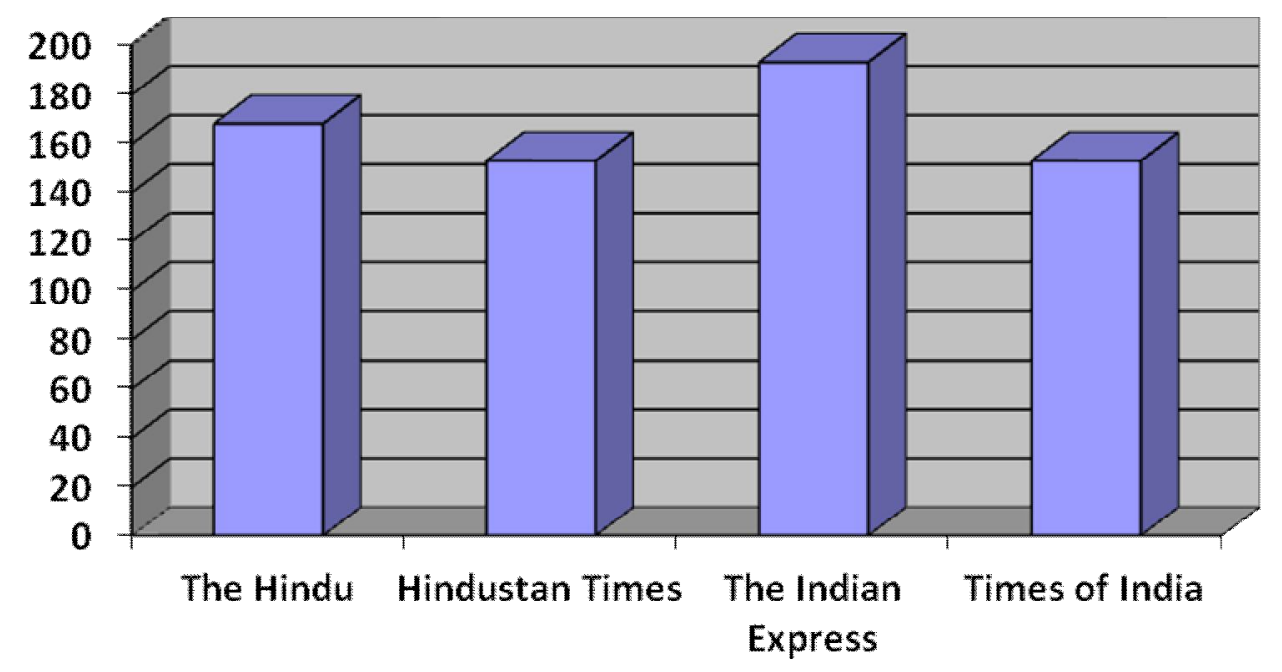


The stories which are most often reported where related to terrorism. Total number of stories covered in the four national dailies are 667 out of which The Hindu covered 168, Hindustan Times and Times of India reported 153 each while The Indian Express covered 193 stories. The terrorism stories related with Pakistan are reported more frequently.

3. To study the crime news most often published

Highest space coverage is given to stories related to terrorism (Hindu - 20,466.72 sq cm, Hindustan Times - 21,533.90 sq cm, The Indian Express - 34,510.08 sq cm and Times of India 20,133.69 sq cm) followed by crime involving politicians (The Hindu $-7,474.30 \mathrm{sq} \mathrm{cm}$, Hindustan Times - 6,411.81 sq cm, The Indian Express - 11,731.15 sq cm and The Times of India- 6,944.32 sq $\mathrm{cm})$.

Least coverage is given to eve teasing cases (The Hindu - 22.57 sq $\mathrm{cm}$ and The Indian Express $80.18 \mathrm{sq} \mathrm{cm}$ ) followed by drunken driving by the youth (The Hindu $\mathbf{- 1 2 2 . 5 0 \mathrm { sq }} \mathrm{cm}$ and The Indian Express $61.06 \mathrm{sq} \mathrm{cm}$ ) and female infanticide cases (The Hindu - $27.72 \mathrm{sq} \mathrm{cm}$, The Indian Express $18.50 \mathrm{sq} \mathrm{cm}$ and Times of India $-175.75 \mathrm{sq} \mathrm{cm}$ ).

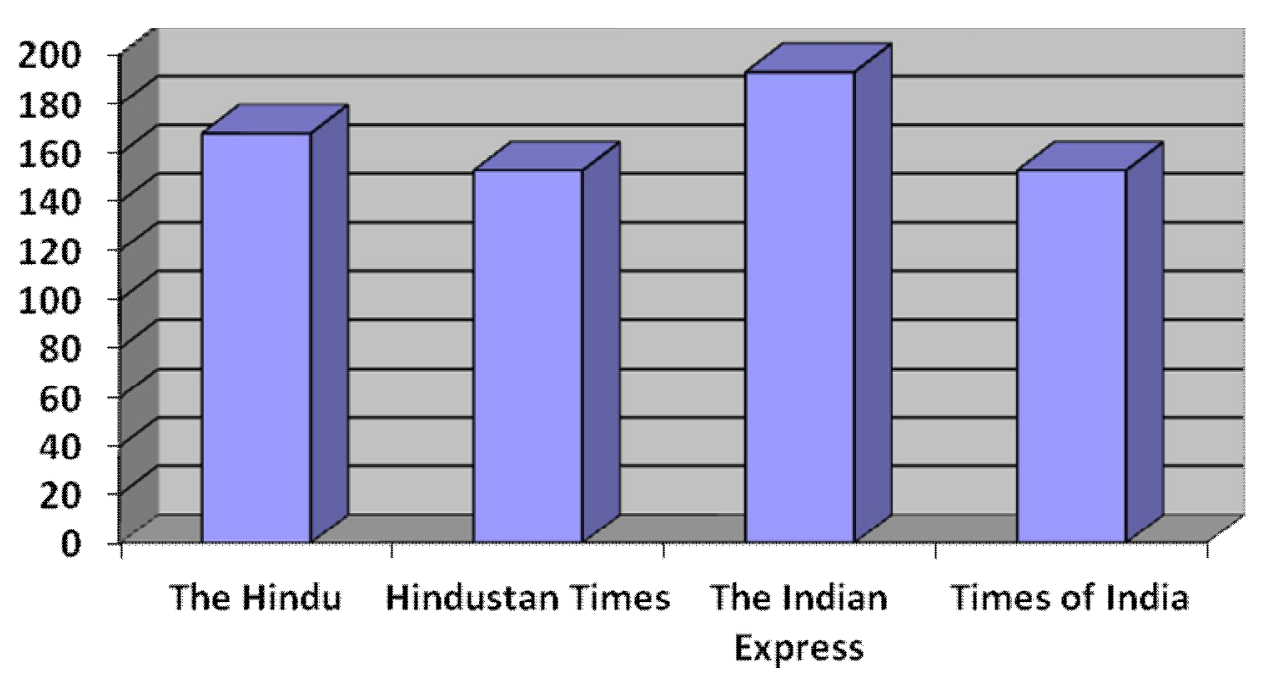

4. Crimes done by woman, youth and children

a) Crime done by women: Not many stories about crime done by women are covered by the four national dailies. Times of India (44) published the maximum number of stories under this head followed by Hindustan Times (42), The Indian Express (28) and The Hindu (20). The published stories are related to murder, suicide, fraud and terrorist activities. Murder and suicide are generally done by middle aged women due to family problems and extra marital affairs.

b) Crime done by youth: It was studied under four categories - Eve teasing, Rape, Drunken Driving and Others. In The Hindu the space coverage to such stories was $6.85 \%$, in Hindustan Times was $4.93 \%$, in The Indian Express was $4.56 \%$ and in Times of India was $10.85 \%$. In terms of the number of stories published covering crime done by youth, the coverage given to such stories in The Hindu was $4.66 \%$, in The Hindustan Times was 5.37\%, in The Indian Express was $2.14 \%$ and in Times of India it was $3.82 \%$.

c) Crime done by children: Such stories have been least reported by the newspapers. Only two stories were published under this head in The Hindu. The first story related to a suicide case and 
the second story related to eight juveniles who escaped from jail. In Hindustan Times 10 stories were published. Some serious offences were also published like threatening the minister, murder, suicide and children involved in making bombs. In The Indian Express, 4 news stories were published during the year. Stories related to serious offences by children were published like murder and terrorist activities. In Times of India 15 stories were published and almost $98 \%$ of the stories were related to crime done by children in foreign countries. Serious offences like murder were also published. It is to be noted that students who made a hoax call to get an off from the school was published in three newspapers - Hindustan Times, The Indian Express and Times of India.

5. To study the crime done by bureaucrats, politicians and influential people

a) Crime done by bureaucrats: The Indian Express (47) published the maximum number of crime stories under this head followed by Hindustan Times (38), The Hindu (37) and Times of India (28). The news which was covered by most of the national dailies was related with SP, Auraiya who was suspended and which was published in Hindustan Times and The Hindu on ist January, 2009. News related with Virk, Police Chief of Maharashtra who was allegedly involved in poll malpractices was published on 6th of March in three national dailies, i.e., Hindustan Times, The Indian Express and Times of India. Narnaul's suicide case was published in Hindustan Times and Times of India. Graft case was published in The Hindu, The Indian Express and Times of India on 1st of May. The news about Ahluwalia's suspension orders which were revoked was published in Hindustan Times and Times of India on 18th of June. The news of an IAS officer involved along with Ashok Sehgal in a bribery case was published in The Hindu and Hindustan Times on 12th of July. EC notice to Pawar was published in Indian Express and Times of India on 8th of October. Himachal IG, Jagjeet Kumar who committed suicide by shooting himself was published in Hindustan Times and Times of India on 9th of November. The Rathore case related to his medal and pension was covered by Hindu and Indian Express on 27th of December.

b) Crime done by politicians: Maximum attention to this head was given by The Indian Express (77), followed by The Hindu (68), Hindustan Times (64) and Times of India (62). The prominent news which gained media attention under this head was related with SP, Auriya who was suspended and the arrest of BSP MLA Shekhar Tewari. It was published in The Hindu and the Hindustan Times. Ex-DGP Virk who was arrested by the Punjab Vigilance Bureau under the Prevention of Corruption Act in 2007 when he was repatriated to his parent cadre, the Maharashtra Police -- had applied for a Congress ticket from Dasuya for the Assembly elections.

c) Crime done by Influential People: Maximum number of stories were published by The Hindu (37), followed by Hindustan Times (35), Times of India (34) and The Indian Express (25). The stories which received maximum coverage in most of the national dailies were related to Salman Khan and Ajay Devgan who was handed 5 challans for smoking. The news was published in The Indian Express and Times of India on 9th of January, 2009. Muthalik (who is the Chief of Rashtriya Hindu Sena) was to be produced in Virajpet Court. The news was published in Hindustan Times and The Indian Express on 2nd of February. Gurmeet Ram Raheem Singh who is the Chief of Dera Sacha Sauda was granted anticipatory bail and the news was published in Hindustan Times and The Indian Express on 6th of March, 2009. A car banged into the Dutch Royal parade in which four people died and this news was published in Hindustan Times and Times of India on 1st May of 2009. NCSC Chairman, Buta Singh's statement that he will end his life if he was asked to resign was published in Hindustan Times and The Indian Express on 5th of August. The news of the CLB member who was held taking bribe was published in Times of India and The Indian Express on 25th of November. PSEB Chairman's son who was arrested and put 
into police custody was published in Times of India and The Indian Express. The news about Dinakaran being hounded for being a Dalit was published in The Indian Express and Times of India on 19th of December. The news of Charlie Sheen who was arrested for assaulting his wife was published in The Hindu and Hindustan Times on 27th of December, 2009.

7. Crime done to females

The maximum number of stories published under this head were in Hindustan Times (64), followed by Times of India (62), The Indian Express (44) and The Hindu (45). The prominent news which gained media coverage was of an acid attack published on 1st of January, 2009 in all the newspapers. Another news story which was highlighted by the national dailies (The Hindu, Hindustan Times and The Indian Express) was a dowry death case on 2nd of June, 2009 in which husband and in laws burnt the bride to death for dowry.

8. Coverage and content of high profile cases involving people of fame

To study the coverage and content of high profile cases involving people of fame, the four national dailies have been studied throughout the year. It is noted that all the four national dailies have not covered much of the same stories. Only Ramalinga Raju and Kasab news stories have appeared in all the four newspapers. Both the stories have been followed. The story of Ramalinga Raju had appeared 9 times in The Hindu, in Hindustan Times it appeared 11 times, in Times of India and The Indian Express it appeared 8 times each. One more striking feature of both the cases was that the news story headline appeared in more than one deck. The Hindu covered more high profile cases followed by Times of India. Hindustan Times and The Indian Express did not cover much of such stories. Stories related to Hasan Ali, BV Seetaram, Salman, Lalu Prasad Yadav, Digvijay Singh, Medha Patkar, Imran Nazir, Manmohan Singh, Vishal Yadav, Dinakaran, Hooda and Jayapradha appeared in a single newspaper only once. Not enough coverage is given to such stories. The story related to Virbhadra Singh appeared in The Indian Express, Hindustan Times and Times of India but not in The Hindu while the story related to Madhu Koda appeared in The Hindu, The Indian Express and Times of India but not in Hindustan Times.

\section{CONCLUSION}

The research focus is the result of widespread belief among members of the public and its significant influence among public behavior, the general quality of life in local communities and the quality of life in the nation as whole. In this connection, the study attempted to study the response of the readers of the four newspapers in reacting to crime and examining the cognitive distinctions underlying these separate responses.

Reporters are the main content providers of news for the newspaper apart from the news agency. Among the reporters, the crime reporters are those who provide the newsroom with spot stories and interesting incidences of violence, which get prominence in the newspaper. Thus, it was but natural to elicit the views of the crime reporters through focus group discussion as part of the research.

\section{RECOMMENDATIONS}

It is suggested that further studies can be conducted on the basis of the findings of this study. More newspapers, especially local newspapers should be examined to reveal different patterns of reporting of crime news. The findings obtained could be compared with the present findings. 
Studies of the public perception of the phenomenon of crime and the criminal justice system should also be conducted to explore the effect of the media on the audience. For this type of study, Doris Appel Graber's study may help determine the degree to which the public relies on crime news to form their opinion about crime issues and if there is fear of crime among the public that is caused by the media.

\section{REFERENCES}

Arulselvan S. 2016. Role of Media in Making Public Policy on India's Criminal Justice System: A Study of News Reporting on Actor Salman Khan's Acquittal in A Murder Case. Global Media Journal. 2016, 14:26.

Chandan Mukherjee, Preet Rustagi and N. Krishnaji (2001), "Crimes against Women in India: Analysis of Official Statistics” Economic and Political Weekly, Vol. 36, No. 43 (Oct. 27 - Nov. 2, 2001), pp. 4070-4080

Jaclyn Schildkraut (2017), Crime News in Newspapers, http://criminology.oxfordre.com/view/10.1093/acrefore/9780190264079.001.00o1/acrefore9780190264079-e-32

Jason Burke, The problem with crime against women in Delhi, https://www.theguardian.com/commentisfree/2011/feb/22/problem-crime-against-womendelhi

Kaveri Devi Mishra, Sridhar Krishnaswami. 2016. Citizens Journalism in India: a Case Study of Delhi, Journal of Education \& Social Policy Vol. 1 No. 1; June 2014 Kriti Singh, A Small Study On Impact Of Crime Against Women News Stories On Indian Urban, Imperial Journal of Interdisciplinary Research, Vol-2, Issue-3, 2016

Murthy C. S. H. N. et al. 2010. Journal Media and Communication Studies Vol. 2(2) pp. 039-053, February, 2010 